\title{
PRODUKSI HIDROLISAT PROTEIN ANTIOKSIDAN MELALUI HIDROLISIS ENZIMATIK PROTEIN KULIT AYAM BROILER DENGAN ENZIM PAPAIN
}

\author{
N. M. Puspawati*, P. P. Dewi, N. W. Bogoriani dan N. K. Ariati \\ Program Studi Kimia, Fakultas Matematika dan Ilmu Pengetahuan Alam, \\ Universitas Udayana, Jimbaran, Bali, Indonesia \\ *Email: made_puspawati@unud.ac.id
}

\begin{abstract}
ABSTRAK
Penelitian ini bertujuan untuk menentukan aktivitas antioksidan hidrolisat protein yang dihasilkan dari proses hidrolisis enzimatik protein kulit ayam dengan menggunakan variasi konsentrasi enzim papain. Proses hidrolisis dilakukan dengan variasi konsentrasi enzim 1, 3, dan 5\% (b/b protein), pada $\mathrm{pH} 7$, suhu $50^{\circ} \mathrm{C}$ dan waktu hidrolisis 24 jam. Parameter yang diukur meliputi derajat hidrolisis, persen peredaman radikal DPPH (diphenylpicryl hidrazyl), dan komposisi asam amino hidrolisat protein yang paling aktif antioksidan. Hasil penelitian menunjukkan penggunaan konsentrasi enzim yang berbeda menghasikan hidrolisat protein dengan derajat hidrolisis dan persen peredaman DPPH yang berbeda. Penggunaan konsentrasi enzim papain 1, 3, dan $5 \%$ menghasilkan hidrolisat protein dengan derajat hidrolisis berturut-turut sebesar 9,3 $\pm 1,8,18,09 \pm 5,6$, dan $23,15 \pm 6.33 \%$, dan persentase hambatan radikal DPPH pada konsentrasi uji 100 ppm berturut-turut sebesar $16,75 \pm 0,07,58,35 \pm 0,00$, dan $52,99 \pm 0,07 \%$. Hidrolisat protein yang diperoleh menggunakan enzim papain $3 \%$ (b/b protein) menunjukkan persen peredaman tertinggi dengan nilai $\mathrm{IC}_{50} 92,98 \mathrm{ppm}$, memiliki komposisi asam amino tertiggi asam glutamat dan terendah valine.
\end{abstract}

Kata kunci: antioksidan, enzim papain, hidrolisat protein, kulit ayam

\section{ABSTRACT}

This study aimed to determine the antioxidant activity of protein hydrolyzate produced from the enzymatic hydrolysis of chicken skin protein by using variations of the enzyme papain concentration. The hydrolysis process was carried out with variations in the concentration of the enzymes 1,3, and 5\% (w/w protein base), at $\mathrm{pH} 7$, temperature $50^{\circ} \mathrm{C}$, and hydrolysis time 24 hours. The parameters measured including degree of hydrolysis, percentage of inhibition of DPPH radical (diphenylpicryl hydrazyl) and amino acid composition of the protein hydrolyzate with the highest antioxidant activity. The results showed that the use of different enzyme concentrations resulted in protein hydrolyzate with different degrees of hydrolysis and percentage of inhibition of DPPH. The use of papain enzymes 1, 3, and 5\% produced protein hydrolyzate with the degree of hydrolysis of $9.3 \pm 1.8,18.09 \pm 5.6$, and $23.15 \pm 6.33 \%$, and the percentage of inhibition of DPPH radical at a concentration of $100 \mathrm{ppm} 16.75 \pm 0.07,58.35 \pm 0.00$, and $52.99 \pm 0.07 \%$ respectively. Protein hydrolyzate obtained using the enzyme papain 3\% (w/w protein) exhibited the highest percentage of inhibition of DPPH with an $\mathrm{IC}_{50}$ value of $92.98 \mathrm{ppm}$, having the highest amino acid composition of glutamic acid and the lowest valine.

Keywords: antioxidant, enzyme papain, protein hydrolyzate, chicken skin

\section{PENDAHULUAN}

Hidrolisat protein merupakan campuran oligopeptida, asam amino bebas, dan peptida yang diperoleh dari hidrolisis parsial protein (Nasri et al., 2017). Hidrolisis protein dapat dilakukan secara kimia, termal, fermentasi, dan enzimatis (Samanarayaka et al., 2011). Hidrolisis secara enzimatis lebih banyak digunakan karena lebih mudah dikontrol dan tidak merusak struktur asam amino serta aman untuk produk pangan (Kim, 2013). Sumber protein dapat berasal dari tumbuhan (kacangkacangan), hewan (daging, telur, susu dan olahannya) maupun by-product (kulit, tulang, kepala, jeroan, mata ceker) (Onuh et al., 2015). Enzim yang digunakan dapat berasal dari mikroba (alcalase), hewan (pepsin, tripsin), dan tumbuhan (papain, bromelin) (Onuh et al., 2015)

Pada umumnya hidrolisat protein dimanfaatkan sebagai bahan makanan tambahan karena nilai gizinya tinggi dari asam aminonya, sebagai penguat rasa, kosmetik, dan 
kesehatan (Castro dan Sato, 2015). Peptida yang yang terkandung pada hidrolisat protein juga dilaporkan dapat bersifat bioaktif diantaranya sebagai antioksidan, antibakteri, antikanker, dan antihipertensi (Castro dan Sato, 2015). Bioaktivitas dari hidrolisat protein bergantung pada sumber substrat, jenis enzim, suhu, $\mathrm{pH}$, dan waktu yang digunakan pada proses hidrolisis (Elevarsan et al., 2014).

Peptide bioaktif antioksidan yang berasal dari hasil sampimg pengolahan ikan telah banyak dilaporkan (Baehaki, 2015). Namun masih sedikit penelitian yang mengkaji aktivitas antioksidan hidrolisat protein yang berasal dari limbah industri pengolahan daging ayam seperti kulit ayam. Hidrolisat protein kulit ayam yang diproduksi dari hidrolisis enzimatik kulit ayam menggunakan enzim alcalase dan gastrointestinal dilaporkan bersifat aktif antioksidan (Onuh et al., 2014). Sejauh ini belum ada penelitian yang mengkaji potensi kulit ayam Broiler sebagai sumber hidrolisat protein aktif antioksidan yang diproduksi melalui hidrolisis enzimatik dengan enzim papain. Beberapa penelitian melaporkan enzim papain efektif digunakan dalam produksi hidrolisat protein yang aktif antioksidan seperti produksi hidrolisat protein antioksidan dari mata tuna (Mutaminah et al., 2018), ikan patin (Baehaki et al., 2015), catfish (Najafian et al., 2014) dan ceker ayam (Susanto et al., 2018). Penelitian ini dilakukan dengan tujuan untuk mengevaluasi aktivitas antioksidan hidrolisat protein yang diproduksi melalui hidrolisis kulit ayam menggunakan enzim papain.

\section{MATERI DAN METODE}

\section{Bahan}

Bahan penelitian yang digunakan adalah kulit ayam yang dibeli dari peternakan Ciomas, Tabanan. Bahan kimia yang digunakan meliputi crude enzim papain (Paya yang diperoleh dari supermarket lokal), $n$-heksana teknis, akuademineral, asam klorida, natrium asetat, etanol p.a., natrium hidroksida, kristal $\mathrm{DPPH}$, ninhidrin, dan asam amino leusin yang berderajat pro analisis.

\section{Peralatan}

Alat yang digunakan pada penelitian ini yaitu seperangkat alat gelas, pipet mikro, termometer,vortex, waterbath shaker Shel Lab SWBR 27-2, sentrifugasi Centurion BRK
5436, soxhlet extractor, freez drier, UV-Vis Biochrome S26, HPLC.

\section{Cara Kerja \\ Preparasi sampel}

Kulit ayam dibersihkan dengan air mengalir untuk menghilangkan kotorankotoran dan lemak yang menempel di permukaan, kemudian dipotong kecil-kecil (2 $\mathrm{cm})$ dan dikeringkan dengan freeze dryer selama 2 hari. Kulit ayam yang telah kering selanjutnya dihaluskan menggunakan blender sampai diperoleh serbuk kulit ayam. Kemudian serbuk kulit ayam diektraksi dengan soxhlet extractor mengunakan pelarut n-heksana untuk menghilangkan lemaknya. Serbuk sampel setelah diekstraksi lemaknya kemudian dipanaskan dalam oven pada suhu $40^{\circ} \mathrm{C}$ untuk menghilangkan residu $n$-heksananya. Sampel kulit ayam bebas lemak kemudian dianalisis kandungan proksimatnya.

\section{Pembuatan hidrolisat protein}

Pembuatan hidrolisat protein dilakukan melalui variasi konsentrasi enzim papain $(1,3$, dan $5 \%$ b/b protein) dengan waktu konstan 24 jam untuk mendapatkan konsentrasi enzim terbaik. Serbuk kulit ayam bebas lemak dicampur dengan akuades $(5 \% \mathrm{~b} / \mathrm{v}), \mathrm{pH}$ nya diatur 7 (dengan menambahkan $2 \mathrm{M} \mathrm{NaOH}$ ) dengan suhu $50^{\circ} \mathrm{C}$ kemudian dilakukan proses pra-hidrolisis menggunakan waterbath shaker dengan kecepatan 60 rpm selama 20 menit. Enzim papain kemudian ditambahkan dengan variasi konsentrasi enzim 1,3 , dan $5 \%$ (b/b protein) dan dihidrolisis menggunakan waterbath shaker dengan kecepatan $60 \mathrm{rpm}$ pada suhu $50^{\circ} \mathrm{C}, \mathrm{pH} 7$ dan diinkubasi selama 24 jam. Setelah proses inkubasi 24 jam, reaksi dihentikan dengan pemanasan pada suhu $85^{\circ} \mathrm{C}$ selama 10 menit. Masing-masing hidrolisat protein yang diperoleh disentrifugasi selama 15 menit kemudian supernatannya ditampung dan disimpan dalam botol kaca gelap pada suhu $-15^{\circ} \mathrm{C}$.Selanjutnya hidrolisat protein dikeringkan menggunakan freeze dryer.

\section{Penentuan derajat hidrolisis secara spektrofotometri}

Satu seri larutan standar asam amino (yang diwakili oleh leusin) disiapkan dengan mengencerkan larutan stok leusin $0,2 \mathrm{~mm}$ menggunakan pelarut yang sama yang digunakan untuk menyiapkan larutan sampel 
protein dan sebanyak $0,2 \mathrm{ml}$ reagen ninhidrin ditambahkan. Sebanyak $0,2 \mathrm{ml}$ reagen ninhidrin juga ditambahkan ke dalam masingmasing $1 \mathrm{ml}$ larutan hidrolisat protein hasil perlakuan, ke dalam $1 \mathrm{ml}$ larutan blanko, dan 1 $\mathrm{ml}$ larutan protein yang tidak dihidrolisis. Semua campuran selanjutnya dibaca absorbansinya pada panjang gelombang $(\lambda)$ $570 \mathrm{~nm}$ menggunakan spektrofotometer UVVis. Kurva kalibrasi larutan standar leusin dibuat dengan cara memplot nilai absorbansi Vs konsentrasi asam amino. Jumlah gugus amino yang dilepaskan $(h)$ ditentukan dengan cara mengurangi nilai kontrol yang tidak terhidrolisis pada kurva standar yang berhubungan setelah blangkonya dihitung. Hal ini akan memberikan jumlah ekivalen ikatan peptida yang terhidrolisis $(h)$, yang dinyatakan sebagai miliekivalen per gram protein dari persamaan berikut menurut Alder-Nissen (1986):

Keterangan:

$$
h=(A x b) / m
$$

$\mathrm{A}=$ absorbansi pada $570 \mathrm{~nm}$

$b=$ intersep pada sumbu y

$m=$ slope dari kurva

kalibrasi

Derajat hidrolisis (DH) dapat dihitung mengikuti persamaan berikut:

$$
\mathrm{DH}=h / h_{\text {total }} \times 100 \%
$$

$h_{\text {total }}$ merupakan jumlah ikatan peptida total (yang diperoleh dari rekonstitusi sampel protein $(b / v)$.

\section{Uji aktivitas antioksidan}

Aktivitas antioksidan hidrolisat protein dalam menghambat hasil radikal DPPH dinyatakan sebagai persen peredaman. Sebanyak $2 \mathrm{ml}$ masing-masing larutan hidrolisat protein hasil perlakuan dicampur dengan 0,5 $\mathrm{ml}$ etanol 99,5\% dan 0,5 ml DPPH $0,02 \%(\mathrm{~b} / \mathrm{v})$. Campuran ini disimpan pada ruang gelap pada suhu kamar selama 30 menit sebelum diukur absorbansinya dengan menggunakan spektrofotometer UV-Vis pada panjang gelombang ( $\lambda$ ) $517 \mathrm{~nm}$. Untuk menghitung $\%$ peredaman dari hidrolisat protein kulit ayam digunakan rumus berikut ini.
$\%$ Peredaman $=\frac{\text { Abs.blangko-Abs.sampel }}{\text { Abs.blangko }} \times 100 \%$

\section{Analisis komposisi asam amino}

Sebanyak 0,2 g sampel hidrolisat protein yang diperoleh dengan enzim papain 3\% dimasukkan dalam tabung reaksi tertutup dan ditambahkan sebanyak $5 \mathrm{~mL} \mathrm{HCl} 6$ N. Sampel kemudian dimasukkan dalam oven dengan suhu $100^{\circ} \mathrm{C}$ selama $18-24$ jam. Selanjutnya sampel disaring dengan kertas saring Whatman 40. Hasil hidrolisis dipipet sebanyak $10 \mu \mathrm{l}$ dan dimasukkan ke dalam tabung reaksi. Kemudian ditambahkan $30 \quad \mu l$ larutan pengering, lalu dikeringkan dengan pompa vacuum. Sampel yang telah dikeringkan ditambahkan larutan derivate sebanyak $30 \mu 1$ dan dibiarkan kering selama 20 menit. Sampel kemudian diencerkan dengan $200 \mu \mathrm{l}$ larutan pengencer natrium asetat $1 \mathrm{M}$. Sampel siap dianalisis dengan HPLC.

\section{Analisis Data}

Data yang diperoleh untuk masingmasing perlakuan dengan $3 \mathrm{x}$ pengulangan dianalisis dengan ANOVA dengan software statistik (SPSS). Untuk mengetahui adanya perbedaan yang signifikan $(\mathrm{p}<0,05)$ antar perlakuan maka dilanjutkan dengan uji berganda LSD .

\section{HASIL DAN PEMBAHASAN}

\section{Hasil preparasi sampel dan analisis proksimat}

Pada penelitian ini sampel kulit ayam yang digunakan adalah serbuk sampel kering beku. Serbuk kulit ayam kering beku dilaporkan mengandung $18,07 \%$ protein dan $67,85 \%$ lemak (Puspawati et al., 2015). Kandungan lemak yang tinggi pada sampel dapat mengganggu proses hidrolisis sehingga dilakukan proses ekstraksi lemak dengan extraksi Soxhlet. Dari hasil analisis proksimat seperti disajikan pada Tabel 1, kandungan lemak sampel setelah proses ekstraksi berkurang menjadi $6,45 \%$ dan kandungan proteinnya meningkat menjadi $75,38 \%$. Hal ini menunjukkan bahwa proses ekstraksi lemak dengan metode soxhlet efisien dalam menurunkan kadar lemak sampel kulit ayam. 
Tabel 1. Komposis Kimia Serbuk Kulit Ayam Kering Bebas Lemak

\begin{tabular}{cc}
\hline Komposisi Kimia & $\%$ \\
\hline Air & 7,84 \\
Protein & 75,48 \\
Lemak & 6,45 \\
Abu & 2,56 \\
Karbohidrat & 8,56 \\
\hline
\end{tabular}

Kandungan protein yang tinggi $>70 \%$ atau disebut konsentrat protein pada sampel kulit ayam sangat baik digunakan sebagai sumber protein untuk menghasilkan hidrolisat protein.

\section{Hasil penentuan derajat hidrolisis}

Derajat hidrolisis adalah rasio antara persen ikatan peptida y.ang putus selama proses hidrolisis dan jumlah total ikatan peptida dalam substrat protein (Bougatef et al, 2012). Pada penelitian ini, derajat hidrolisis ditentukan dengan metode spektrofotometri UV-Vis. Hasil penentuan derajat hidrolisis disajikan pada Tabel 2. Nilai derajat hidrolisis dipengaruhi oleh konsentrasi enzim yang digunakan. Semakin tinggi konsentrasi enzim yang digunakan maka kecendrungan nilai derajat hidrolisisnya juga meningkat yang mengindikasikan semakin banyaknya ikatan peptida yang putus.

Tabel 2. Derajat Hidrolisis Hidrolisat Protein Dengan Variasi Konsentrasi Enzim

\begin{tabular}{cc}
\hline $\begin{array}{c}\text { Konsentrasi Enzim } \\
(\% \text { b/b protein })\end{array}$ & $\begin{array}{c}\text { Derajat } \\
\text { Hidrolisis }(\%)\end{array}$ \\
\hline 1 & $9,31 \pm 1,81^{\mathrm{a}}$ \\
3 & $18,09 \pm 5,6^{\mathrm{b}, \mathrm{c}}$ \\
5 & $23,15 \pm 6,34^{\mathrm{b}, \mathrm{c}}$ \\
\hline
\end{tabular}

Hasil analisis statistik dengan ANOVA dan dilanjutkan uji perbandingan berganda dengan uji LSD menunjukkan bahwa nilai derajat hidrolisis protein dengan menggunakan enzim $1 \%(9,31 \%)$ berbeda nyata dengan nilai derajat hidrolisis protein dengan konsentrasi enzim 3\% dan 5\% (18,09\% dan 23,15\%). Namun nilai derajat hidrolisis protein yang diperoleh dengan konsentrasi enzim 3\% tidak berbeda nyata dengan 5\%. Penelitian yang dilakukan Mutaminah et al.(2018) juga mendapatkan hasil bahwa terjadi kecenderungan kenaikan derajat hidrolisis dengan meningkatnya konsentrasi enzim papain yang digunakan untuk memproduksi hidrolisat protein antioksidan dari mata tuna (Mutaminah et al., 2018).

Beveridge (1996) menjelaskan selama proses hidrolisis berlangsung sisi aktif katalitik papain yaitu gugus sistin dan histidin akan memutus rantai peptida substrat protein menjadi produk. Selama proses tersebut terjadi perubahan struktural diantara enzim dan substrat yang mana gugus sistin yang sangat reaktif akan berikatan dengan substrat membentuk ikatan kovalen enzim-substrat yang berbentuk tetrahedral. Sementara itu, gugus histidin terprotonasi dan berikatan dengan nitrogen pada substrat sehingga mengakibatkan gugus amina pada substrat akan terdifusi dan posisinya digantikan oleh molekul air yang akhirnya menghidrolis produk intermediet dan enzim kembali ke fungsi dan bentuknya semula (Beveridge, 1996). Mekanisme hidrolisis ikatan peptida dengan enzim papain dapat dilihat pada Gambar 1.

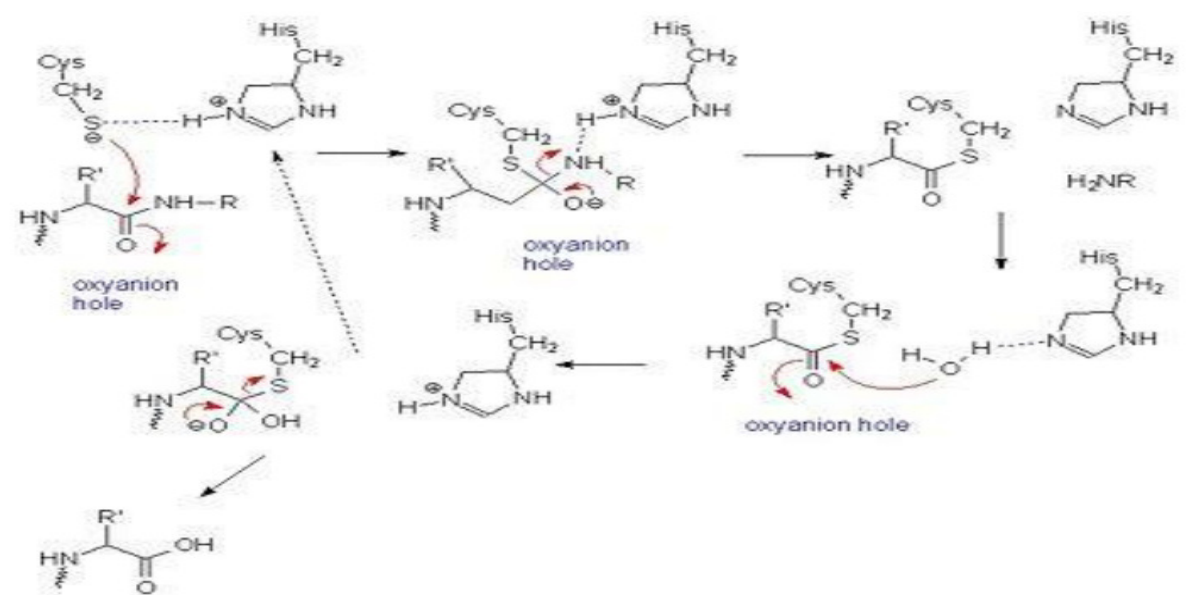

Gambar 1. Mekanisme Hidrolisis Ikatan Peptida Dengan Enzim Papain 


\section{Hasil penentuan aktivitas antioksidan}

Antioksidan adalah molekul yang dapat bereaksi dengan radikal bebas membentuk senyawa yang stabil sehingga reaksi oksidasi dapat berhenti (You et al., 2009). Senyawa antioksidan mampu meredam radikal DPPH karena kemampuannya dalam mendonorkan proton atau elektron sehingga senyawasenyawa radikal menjadi lebih stabil (You et $a l$., 2009). Persen peredaman radikal DPPH yang menyatakan aktivitas antioksidan hidrolisat protein hasil perlakuan pada konsentrasi 100 ppm disajikan pada Tabel 3.

Tabel 3. Persen Peredaman Hidrolisat Protein Hasil Perlakuan

\begin{tabular}{cc}
\hline $\begin{array}{c}\text { Konsentrasi Enzim } \\
(\% \mathrm{~b} / \mathrm{b} \text { protein })\end{array}$ & $\begin{array}{c}\text { Persen peredaman } \\
(\%)\end{array}$ \\
\hline 1 & $16,75 \pm 0.07^{\mathrm{a}}$ \\
3 & $58,35 \pm 0,00^{\mathrm{b}}$ \\
5 & $52,99 \pm 0.07^{\mathrm{c}}$ \\
\hline
\end{tabular}

Hasil analisis secara statistik menunjukkan bahwa konsentrasi enzim berpengaruh secara signifikant terhadap aktivitas antioksidan. Persen peredaman radikal bebas oleh hidrolisat protein meningkat dengan meningkatnya konsentrasi enzim sampai batas tertentu (3\%). Hidrolisat protein yang diperoleh dengan enzim papain $1 \%$ hanya mampu meredam radikal DPPH sebesar $16,75 \%$, dengan konsentrasi $3 \%$ meningkat menjadi 58,35\%. Namun hidrolisat protein dengan menggunakan konsentrasi enzim $5 \%$ memberikan persen peredaman DPPH 52,99\% yang nilainya lebih rendah dari konsentrasi enzim 3\%. Baehaki et al. (2015) juga mendapatkan hasil yang sama yaitu persen peredaman hidrolisat protein dari ikan patin meningkat dengan meningkatnya konsentrasi enzim sampai batas tertentu dan kemudian mengalami penurunan (Baehaki et al., 2015). Aktivitas antioksidan juga bisa dinyatakan dengan nilai $\mathrm{IC}_{50}$ yaitu konsentrasi sampel yang mampu menghambat 50\% radikal DPPH. Hasil penentuan nilai $\mathrm{IC}_{50}$ menunjukkan bahwa hidrolisat protein yang diproduksi dengan enzim papain $3 \%$ memberikan nilai $\mathrm{IC}_{50} 92,98$ ppm yang termasuk katagori kuat (Molyneux, 2014). Mekanisme antioksidan protein atau peptida bergantung pada jenis atau komposisi asam aminonya penyusunnya (sebagai donor elektron, proton, pengkelat logam, pereduksi hidroperoksida).

\section{Hasil analisis komposisi asam amino}

Komposisi asam amino hidrolisat protein pangan memiliki berbagai peran dalam aktivitas fisiologisnya termasuk sebagai antioksidan. Hasil analisis komposisi asam amino hidrolisat protein kulit ayam dengan aktivitas antioksidan tertinggi yang diproduksi dengan enzim 3\% disajikan pada Tabel 4.

\begin{tabular}{cc}
$\begin{array}{c}\text { Tabel 4. Komposisi hidrolisat protein } \\
\text { kulit ayam dengan enzim } 3 \%\end{array}$ \\
\hline $\begin{array}{c}\text { Asam Amino } \\
(\mathrm{g} / 100 \mathrm{~g})\end{array}$ & $\begin{array}{c}\text { Hidrolisat protein } \\
\text { kulit ayam }(\%)\end{array}$ \\
\hline ASP & 3,71 \\
SER & 0,30 \\
GLU & $\mathbf{2 4 , 5 2}$ \\
GLY & 0,85 \\
HIS & $\mathbf{7 , 0 6}$ \\
ARG & 2,48 \\
THR & 1,66 \\
ALA & 0,03 \\
Prolin & $\mathbf{6 , 2 3}$ \\
CYS & $\mathbf{1 , 4 7}$ \\
TYR & 0,81 \\
VAL & 0,20 \\
MET & 1,01 \\
LYS & 2,83 \\
ILE & 1,32 \\
LEU & 2,71 \\
PHE & 1,82 \\
\hline
\end{tabular}

Seperti terlihat pada Tabel 4, kandungan asam amino tertinggi yaitu asam glutamat yang diikuti dengan prolin, histidin, aspartat, lisin, leusin, arginin, dan yang terendah valine. Mutaminah et al. (2018) melaporkan hidrolisat protein antioksidan dari mata tuna menunjukkan kandungan asam amino glutamat tertinggi dan Chang et al. (2015) juga mendapatkan kandungan asam glutamat tertinggi pada hidrolisat protein antioksidan bluefin leatherjacket. Asam amino yang bermuatan negatif seperti glutamat dan aspartat dilaporkan mempunyai aktivitas antioksidan yang kuat karena kemampuannya untuk mendonorkan kelebihan elektronnya dalam reaksi radikal bebas (He, et al., 2013; Samanarayaka et al., 2011). Asam amino yang juga berkontribusi terhadap aktivitas antioksidan adalah prolin dan lisin dengan mendonorkan protonnya dan histidin dengan mengkelat logam (He, et al., 2013; Naqash and Nazeer, 2011). 


\section{SIMPULAN}

Penggunaan konsentrasi enzim papain 1, 3 , dan $5 \%(\mathrm{~b} / \mathrm{b}$ protein) menghasilkan hidrolisat protein dengan derajat hidrolisis berturut-turut sebesar 9,3 $\pm 1,8,18,09 \pm 5,6$, dan $23,15 \pm 6.33 \%$, dan persentase peredaman radikal DPPH pada konsentrasi uji $100 \mathrm{ppm}$ berturut-turut $16.75 \pm 0,07, \quad 58,35 \pm 0,00$, dan $52,99 \pm 0,07 \%$. Hidrolisat protein yang diperoleh dengan enzim papain $3 \%$ (b/b protein) menunjukkan aktivitas antioksidan kuat dengan nilai $\mathrm{IC}_{50} 92,98 \mathrm{ppm}$, dengan kandungan asam amino glutamat tertinggi dan valine terendah.

\section{UCAPAN TERIMAKASIH}

Terima kasih kepada Fakultas MIPA Universitas Udayana, yang telah mendanai penelitian ini melalui skim PUPS tahun anggaran 2019.

\section{DAFTAR PUSTAKA}

Aluko, R. E and Monu, E. 2003. Functional and bioactive of quinoa seed protein hydrolysate. Journal of Food Sciences. 68: 1254-125.

Baehaki, A., Lestari, S. D., Romadhoni, A. R., 2015. Hidrolisis Protein Ikan Patin Menggunakan Enzim Papain dan Aktivitas Antioksidan Hidrolisatnya. JPHPI. 18(3): 108-118.

Beveridge, A.J. 1996. A Theoretical study of the active sites of papain and s195c rat tripsin:implication for the low reactivity of mutant serine proteinases. Journal Protein Sciences. 5:1355-1365.

Bougatef, A., Balti, R., Haddar, A., Jellouli, K., Souissi, N., Nasri, M. 2012. Antioxidant and functional properties of protein hydrolysates of bluefin tuna (Thunnus thynnus) head as influenced by the extent of enzymatic hyrolysis, Biotechnology and Bioprocess Engineering. 17: 841-852.

Castro, R. J. S., dan Sato, H. H. 2015. Review: Biologically active peptides: Process for their generation, purification and identification and application as natural additives in the food and pharmaceutical industries. Food Research International. 74: 185-198.
Chang, F.C., Bin, W., Yu, M.W., Bin, Z., Shang, G.D. 2015. Isolation and characterisation three antioxidant peptides from protein hydrolisate of bluefin leatherjacket (Navodon septenrionalis) heads. Jurnal of Functional Food. 12: 1-10.

Elevarsan, K., Naveen Kumar, V., Shamasundar, B. A. 2014. Antioxidant and Functional Properties of Fish protein Hydrolysate from Fresh Waer Carp (Catla-Catla) as influenced by the nature of enzyme. J. Food. Process.Press. doi:10.1111/jfpp.12081

He, R., Girgih, A.T., Malomo, S. A, Ju, X. R, Aluko, R.E. 2013. Antioxidant activities of enzymatic rapeseed protein hydrolysates and the membrane ultrafiltration fraction. Journal of Functional Food. 5(1): 219-227.

Kim, EK. 2013. Marine Protein and Peptides, Biological Activities, Oxford (UK):John Wiley and Sons.

Molyneux, P., 2004, The use of the stable free radical diphenylpicrylhydrazil (DPPH) for estimating antioidant activity, Journal Science and Technology, 26 (2):211-219.

Mutaminah, D., Ibrahim B., Trilaksani, W., 2018. Antioxidant activity of protein hydrolysate produced from tuna eye (Thunnus sp) by enzymatic hydrolysis. JPHPI. 21(3): 522-531.

Najafian, L., Abdul S.B. 2014. Production of bioactive peptides using enzymatic hydrolysis and identification antioxidative peptides from patin (Pangasius sutchi) sarcoplasmic protein hydrolysate. Journal of Functional Food. 9 (3): 280-289.

Naqash, S. Y. and Nazeer, R. A. 2014. Evaluation of bioactive peptides isolated from Exocoetus volitan backbone, International Journal of Food Sciences and Technology. 46: 37-43.

Nasri, M. 2017. Protein hydrolysate and biopeptide: Production, biological activities, and application in food and health benefit: A review. Advanced in Food and Nutrition Research. 81:105109.

Onuh, J. O. 2015. Antyhypertensive and Antioxidant Properties of Chikcen Skin Protein Hydroysates: In vivo, in vitro, 
and metabolomic studies. Thesis. Faculty Of Grdauate Studies, The University of Manitoba.

Onuh, J. O., Girgih, A. T., Aluko, R. E, Aliani, M. 2014. In vitro antioxidant properties of chicken skin enzymatic protein hydrolysates and membrane fractions, Food Chem. 150: 366-373.

Puspawati, N. M., Widihati, I. G, dan Widana, N. 2015. Analisis Komposisi Asam Amino dan Pola Pita protein Gelatin Halal dari Kulit Ayam Broiler, Laporan Penelitian Unggulan Program Studi, FMIPA, Universitas Udayana.

Samanarayaka, E. G. P. and Li-Chan, E. C. Y., 2011. Food-derived peptidic antioxidant: a review of their production, assesment and potential applications. Journal of Functional Food. 3:229-254.

Susanto, E, Rosyidi, D., Radiati, L. E. 2018. Optimasi aktivitas peptida aktif dari ceker ayam melalui hidrolisis enzim papain, Jurnal Ilmu dan Teknologi Hasil Ternak. 13(1): 14-26.

You, L., Zhao, M., Cui, C., Zhao, H., Yang, B. 2009. Effect of degree of hydrolysis on the antioxidant activity of loach (Misgurnusanguilli caudatus) protein hydrolysates. Innovative Food Sciences and Emerging Technology. 10(2): 235240. 